\title{
Evaluation of acquired passive immunity in mule foals up to 60 days of age
}

\author{
Vivian dos Santos BAPTISTA ${ }^{1}$, Paula de Mattos GUTTMANN ${ }^{2}$, Ana Garolina RUSCA ${ }^{3}$, \\ Kátia Moreira da SILVA ${ }^{1}$, Daniel de Barros MACIEIRA ${ }^{4}$, Nayro Xavier de ALENGAR ${ }^{4}$ \\ and Daniel Augusto Barroso LESSA ${ }^{4 *}$ \\ ${ }^{1}$ Graduate Program in Veterinary Medicine (Clinical Sciences and Animal Reproduction), Universidade Federal \\ Fluminense, Niterói 24230-340, Brazil \\ ${ }^{2}$ DVM, Equine Private Practitioner, 25953-236, Brazil \\ ${ }^{3}$ Student Coordinator's Office, College of Veterinary Medicine, Universidade de Sorocaba, Sorocaba 18023-000, \\ Brazil \\ ${ }^{4}$ Department of Pathology and Veterinary Clinics, Universidade Federal Fluminense, Niterói 24230-340, Brazil
}

Ten mule foals were used to investigate serum IgG concentration. Blood was collected from mares and foals on the day following parturition (D1), at 48 and $72 \mathrm{hr}$ after birth (D2 and D3), and on D7, D14, D21, D28, D35, D42, and D60. Serum IgG concentration was determined by zinc sulfate turbidity test and was above $400 \mathrm{mg} / \mathrm{dl}$ at all time points, except for one foal on D2. Mean values were above $800 \mathrm{mg} / \mathrm{dl}$ from D1 to D7 and at D60. The difference between mares and foals at each collection time was significant, except at $D 1$. For all other days, foal $\operatorname{Ig} G$ values were lower than the mare $\operatorname{Ig} G$ values. Mean $\operatorname{Ig} G$ J. Equine Sci.
Vol. 31, No. 1
pp. 1-4, 2020 concentrations were lower from D14 to D42 compared with D1 and D60. The results show that the critical period for the mule foal is at D28, which can be a vulnerable window for infections. The variation pattern in $\operatorname{Ig} G$ values is similar to that in data published for horse and donkey foals. There are no published studies to date on the subject, and the present contribution enables further understanding of the newborn mule foal.

Key words: immune system, immunoglobulins, mule, zinc sulfate

The mule foal is assumed to be born immune naïve, and the passive transfer of colostral immunoglobulins is crucial during the neonatal period. Intrauterine maternal immunity is impaired due to the diffuse epitheliochorial placenta, which acts like a barrier to the passage of large molecules, such as immunoglobulins, resulting in an agammaglobulinemic foal [10]. The placentas of horses and donkeys are structurally similar, with villi diffusely organized in microcotyledons on the entire allantochorion surface [2]. Passive transfer by colostrum ingestion is thus crucial for protection against infections during the neonatal period [7]. Failure of passive transfer has been defined as failure of the

Received: August 16, 2019

Accepted: January 29, 2020

*Corresponding author. e-mail: daniellessa@id.uff.br

C2020 Japanese Society of Equine Science

This is an open-access article distributed under the terms of the Creative Commons Attribution Non-Commercial No Derivatives (by-nc-nd) License. (CC-BY-NC-ND 4.0: https://creativecommons.org/licenses/ by-nc-nd/4.0/) foal to ingest or absorb immunoglobulin from colostrum adequately. Serum IgG reference values in foals at 18 to $24 \mathrm{hr}$ of age are considered normal when above $800 \mathrm{mg} /$ $\mathrm{d} l$. Values within $400-800 \mathrm{mg} / \mathrm{d} l$ are considered to reflect partial failures, and values under $400 \mathrm{mg} / \mathrm{d} l$ reflect the total failure of passive transfer of IgG [3].

IgG levels in colostrum fall dramatically within $24 \mathrm{hr}$ postpartum. The foal must ingest colostrum during the first 2 or $3 \mathrm{hr}$ of age, and within $6 \mathrm{hr}$, IgG is detectable in the serum. The highest IgG level is reached within $18 \mathrm{hr}$, with the serum concentration being similar to the mare's serum concentration. The passive antibody concentration gradually declines until complete absence at 5 months of age. Endogenous immunoglobulin can be detected for the first time at 2 weeks of age, although an adult level is not reached before 5 months of age $[5,6,8]$.

A variety of rapid screening tests are available for IgG estimation. These tests include the zinc sulfate turbidity (ZST) test and enzyme immunoassay (ELISA). The ZST test is based on the precipitation of $\operatorname{IgG}$ when serum is added to 
a solution of zinc sulfate. The degree of turbidity is usually proportional to the concentration of $\operatorname{IgG}[3]$.

Much is known about the perinatal adaptation of the horse foal, and a significant number of studies have been performed with donkey foals $[2,12]$. Nevertheless, there are few studies on the offspring from the crossing of asses and mares, and much still needs to be understood about mule foals. Although these animals seem to be more resistant to adverse conditions and neonatal disease, mule neonate survival is still a major problem in developing countries, where high mortality is due to postpartum conditions as well as poor colostral protection [1]. The aim of this study was to investigate the IgG serum concentration of mule foals from $24 \mathrm{hr}$ until 60 days of age.

\section{Materials and Methods}

This study was done in accordance with the Ethical Principals in Animal Experimentation and approved by the Ethics Committee of the Universidade Federal Fluminense under approval number 432 and was also authorized by the Scientific Directory of the Instituto Vital Brazil, Niterói, Rio de Janeiro.

Ten mule foals ( 5 male and 5 female) born in 2013 and their respective mothers were randomly selected from a herd of 32 mule foals belonging to a farm located in Cachoeiras de Macacu city, Brazil (22 31 ' $1.43^{\prime \prime}$ S / 42 41' 52.18” W), to be analyzed from $24 \mathrm{hr}$ until 60 days postpartum (Fig. 1A). All animals were subjected to prophylactic vaccination and deworming programs routinely utilized at the farm and were tested for Equine Infectious Anemia, as determined by the Brazilian Ministry of Agriculture regulations. All mares were crossbreeds (Fig. 1A), multiparous, from 5 to
20 years old, and from 500 to $780 \mathrm{~kg}$ in weight, and all were mated with one donkey of the Pega breed (Fig. 1B). Gestational length varied between 360 and 375 days. Mule foals were selected and routinely examined according to Sellon's methodology [9]. Parturitions occurred spontaneously and unassisted in a paddock during the night, and the foals were examined on the following day, at which point the first blood sample, considered the 24-hr sample, was collected. A comparison between the first IgG measurement in the foal and in its mother assured adequate colostrum ingestion. All foals used in the study had normal physical examinations throughout the research period.

For the study, $6 \mathrm{~m} l$ of blood was collected from the jugular vein of each mare and her respective foal on the day following parturition. These samples were considered the $24 \mathrm{hr}$ post-delivery (D1) samples. Foals had venous blood collected at 48 (D2) and $72 \mathrm{hr}$ (D3) and at 7, 14, 21, 28, 35,42 , and 60 days of age (D7, D14, D21, D28, D35, D42, and D60). Blood was collected in vacuum tubes without anticoagulant, and all samples were centrifuged at $700 \times \mathrm{g}$ for 7-10 min following clot formation. Serum samples were then stored at $-20^{\circ} \mathrm{C}$ until analysis.

For serum IgG concentration, the samples were thawed at room temperature and analyzed by ZST. A commercial kit $\left(\right.$ TSZ $^{\circledR}$, Embryolab, UFSM, Santa Maria, Rio Grande do Sul, Brazil) developed by Santa Maria Federal University based on Silva et al. [11] was used. After sample thawing, a $100 \mu l$ aliquot was added to a $6 \mathrm{ml} \mathrm{ZnSO}_{4} \cdot 7 \mathrm{H}_{2} \mathrm{O}$ solution and homogenized. Turbidity degree was evaluated within one minute using a spectrophotometer at a wavelength of $450 \mathrm{~nm}$ (Biospectro SP-22) according to the method of Silva et al. [11] and was then compared with a barium chloride standard solution $\left(1.15 \mathrm{~g}\right.$ of $\mathrm{BaCl}_{2} \cdot 2 \mathrm{H}_{2} \mathrm{O} / 100 \mathrm{~m} l$ dissolved

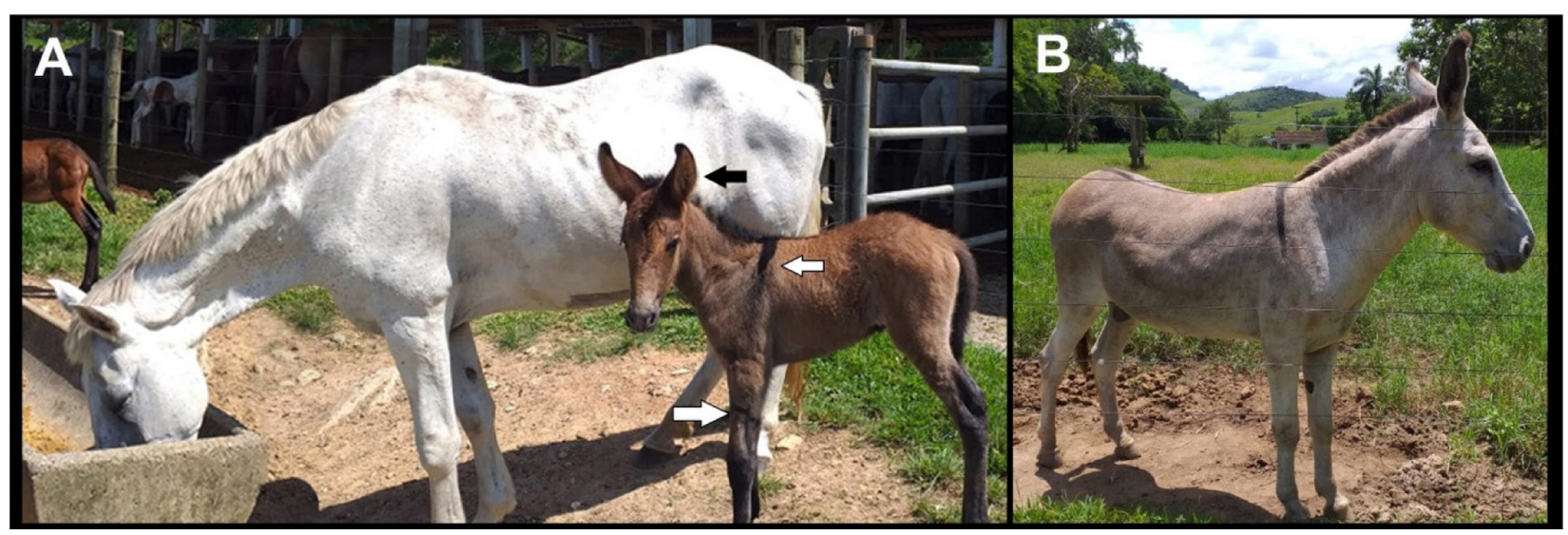

Fig. 1. Animals from the farm where this study was conducted. A, A mare and its mule foal. The arrows show some characteristic features of the mule foal: elongated ears, presence of a shoulder cross, and leg barring or zebra stripes. B, The donkey (Equus asinus) of the Pega breed used for mating with the mares (Equus caballus). 
in $97 \mathrm{ml}$ of $0.2 \mathrm{~N}$ sulfuric acid solution). Absorbance results (t) were applied to a regression equation $(\bar{Y}=20.83+1.13$ $\left.\mathrm{t}-0.0099 \mathrm{t}^{2}\right)$. The analysis of the standard solution was performed under the same conditions as used for the sample, and it resulted in a turbidity reading of 20 turbidity units (tU). Distilled water was used as a plain control. All samples were analyzed in duplicate. Results of spectrophotometer readings were expressed in ZST units and converted to $\mathrm{mg} / \mathrm{d} l$, as described by Silva et al. [11], with $25 \mathrm{tU}$ being equivalent to $450 \mathrm{mg}$ of $\mathrm{IgG}$ per $100 \mathrm{~m} l$ of serum.

Descriptive analyses of the $\mathrm{IgG}$ concentration $(\mathrm{mg} / \mathrm{d} l)$ by ZST test for mares $(n=10)$ and foals $(n=10$; for the time interval of D1 to D60) were reported. The KolmogorovSmirnov test (KST) was performed in order to choose the subsequent analysis. Based on the KST results, the paired Student's $t$-test was used to compare the immunoglobulin concentration of mares versus foals (D1 to D60), foals on D1 versus the following days, and foals on D60 versus previous days. $P$-values $<0.05$ were considered significant for all analyses. Statistical analysis was performed using the SPSS v. 15.0 software (SPSS Inc., Chicago, IL, U.S.A.).

\section{Results}

The IgG concentration was above $400 \mathrm{mg} / \mathrm{d} l$ at all times, except for one foal on D2 (324 mg/d $l)$. Foal IgG on D3 (72 $\mathrm{hr}$ postpartum) varied between $400-800 \mathrm{mg} / \mathrm{d} l$ in four foals and remained above $800 \mathrm{mg} / \mathrm{d} l$ in six foals. On D14, six animals had an IgG concentration between 613 and 740 $\mathrm{mg} / \mathrm{d} l$, and only four foals remained with values above 800 $\mathrm{mg} / \mathrm{d} l$. The mean values were above $800 \mathrm{mg} / \mathrm{d} l$ on D1, D3, $\mathrm{D} 7$, and D60, and the median values were above $800 \mathrm{mg} / \mathrm{d} l$ on D1 to D7 and on D60 (Table 1).

The difference in results from the ZST test when comparing the mares and foals at each collection time was statistically significant, except for D1 $(P=0.086)$. For all other days, the $\operatorname{IgG}$ values of the foals were lower than those of the mares $(P<0.05)$. The mean foal IgG concentra- tions from D14 to D42 were different from those at D1 and D60. The values decreased from D14 to D28 and gradually increased from D35 to D42 (Table 1).

\section{Discussion}

Based on studies on horse and donkey foals [4, 12], the mule foal is assumed to be born immune naive. The results from the ZST test demonstrate adequate $\operatorname{IgG}$ absorption from colostrum ingestion. The mean and median IgG values of foals at all collection times were higher than the values considered to reflect failure of passive transfer of immunity.

The reduction in the IgG concentration from D14 to D28 in the ZST test followed by increasing values close to the D1 values may be due to the consumption of maternal $\mathrm{IgG}$ and production of IgG by the foals. As the ZST test is nonspecific for the species, the increase in values can be ascribed to the IgG production of the foals. Jeffcott [6] showed that levels of passively acquired gamma globulin reach their peak within 12-18 hr after birth and decrease to their lowest recorded values at $4-5$ weeks, rising again to a second peak at 6-8 months. In the same study, two colostrum-deprived foals remained completely agammaglobulinemic until 2 weeks of age but showed a steep rise in gamma globulins at 7-8 weeks of age. According to this same author, catabolism of antibodies and a $46 \%$ reduction in IgG might occur by the fourth week of life, but foals have the ability to synthesize gamma globulin after 2 weeks of life.

A study using an ELISA assay to assess colostral transfer and systemic availability of IgG in horse foals [4] reported the highest $\operatorname{IgG}$ concentration at $13-16 \mathrm{hr}$ postpartum, with the concentration decreasing over time until D35 and increasing at D42 postpartum to values close to the highest concentration observed. In Martina Franca donkey foals, a trend of increase in serum IgG was detected from the time of birth to the maximum level reached at D1, and in spite of a nonsignificant decrease in values, IgG values remained above $4 \mathrm{mg} / \mathrm{ml}$ until D10, the final time point of the study [12].

Table 1. Descriptive analysis of the IgG concentration (mg/d $l$ ) by ZST test for mares (n=10) and foals ( $\mathrm{n}=10$; from D1 to D60), and $P$-values (at $5 \%$ probability) of the paired Student's $t$-test for mares versus foals, D1 versus the following days, and D60 versus previous days, respectively

\begin{tabular}{|c|c|c|c|c|c|c|c|c|c|c|c|}
\hline & Mare & D1 & D2 & D3 & D7 & D14 & D21 & D28 & D35 & D42 & D60 \\
\hline $\begin{array}{l}\text { Mean } \pm \\
\text { SD }\end{array}$ & $\begin{array}{c}1,011.60 \pm \\
103.85\end{array}$ & $\begin{array}{c}910.20 \pm \\
143.10\end{array}$ & $\begin{array}{c}791.20 \pm \\
249.57\end{array}$ & $\begin{array}{c}836.10 \pm \\
192.58\end{array}$ & $\begin{array}{c}864.30 \pm \\
124.35\end{array}$ & $\begin{array}{c}781.40 \pm \\
135.43\end{array}$ & $\begin{array}{c}741.90 \pm \\
75.42\end{array}$ & $\begin{array}{c}718.4 \pm \\
99.31\end{array}$ & $\begin{array}{c}737.20 \pm \\
78.13\end{array}$ & $\begin{array}{c}787.00 \pm \\
97.92\end{array}$ & $\begin{array}{c}883.90 \pm \\
72.05\end{array}$ \\
\hline Median & $1,035.00$ & 943.00 & 821.50 & 867.00 & 808.00 & 767.00 & 717.00 & 704.00 & 745.00 & 792.50 & 875.50 \\
\hline Range & $\begin{array}{l}756.00- \\
1,116.00\end{array}$ & $\begin{array}{l}668.00- \\
1,084.00\end{array}$ & $\begin{array}{l}324.00- \\
1,098.00\end{array}$ & $\begin{array}{l}431.00- \\
1,054.00\end{array}$ & $\begin{array}{l}705.00- \\
1,053.00\end{array}$ & $\begin{array}{l}613.00- \\
1,097.00\end{array}$ & $\begin{array}{c}675.00- \\
899.00\end{array}$ & $\begin{array}{c}539.00- \\
891.00\end{array}$ & $\begin{array}{c}651.00- \\
863.00\end{array}$ & $\begin{array}{c}555.00- \\
920.00\end{array}$ & $\begin{array}{l}799.00- \\
1,039.00\end{array}$ \\
\hline$P$-value* & Reference & $\begin{array}{c}0.086 \\
\text { Reference } \\
0.510\end{array}$ & $\begin{array}{l}0.012 \\
0.106 \\
0.284\end{array}$ & $\begin{array}{l}0.034 \\
0.153 \\
0.415\end{array}$ & $\begin{array}{l}0.021 \\
0.178 \\
0.601\end{array}$ & $\begin{array}{l}0.003 \\
0.005 \\
0.023\end{array}$ & $\begin{array}{l}0.000 \\
0.001 \\
0.000\end{array}$ & $\begin{array}{l}0.000 \\
0.000 \\
0.000\end{array}$ & $\begin{array}{l}0.000 \\
0.000 \\
0.000\end{array}$ & $\begin{array}{l}0.001 \\
0.004 \\
0.014\end{array}$ & $\begin{array}{c}0.012 \\
0.510 \\
\text { Reference }\end{array}$ \\
\hline
\end{tabular}

SD, standard deviation. *Significant value $(P<0.05)$. 
In the present study, one foal had an $\mathrm{IgG}$ concentration of $324 \mathrm{mg} / \mathrm{d} l$ on D2. Nevertheless, this same foal had an IgG concentration of $758 \mathrm{mg} / \mathrm{d} l$ on D1, an IgG concentration of $695 \mathrm{mg} / \mathrm{d} l$ on D4, and a normal clinical exam; therefore, this specific D2 value may have been due to an error in an individual technique used during collection.

Except for D1, there was a significant difference in the mean IgG concentration values of foals when compared with the values of the mares. Nevertheless, the lower values from D2 to D60 are not a biological issue, as the values are higher than that considered to reflect failure of passive transfer of immunity (Table 1).

Since the $\mathrm{IgG}$ values on D1 and D60 were above 800 $\mathrm{mg} / \mathrm{d} l$ and the lowest IgG value in this study was observed on D28 (Table 1), it can be assumed that the critical period for the immune system of the mule foal is the period between D14 and D28, at which time it is more vulnerable to immunologic challenges. This variation pattern in IgG concentration is similar to that in data published for horse foals [6] and donkey foals [12]. This is the first study to evaluate the $\mathrm{IgG}$ serum concentration of mule foals from birth to 60 days of age. As demonstrated here, the most critical period for these animals is from D14 to D28, as the IgG serum concentration decreases rapidly and reaches its lowest values, thus, increasing the chances of infection.

\section{Acknowledgment}

The authors are grateful to Prof. Dr. Mara Iolanda Batistella Rubin, Universidade Federal de Santa Maria (UFSM), Rio Grande do Sul, Brazil, for providing the ZST kit $\left(\mathrm{TSZ}^{\circledR}\right.$, Embryolab, UFSM).

\section{References}

1. Aronoff, N. 2010. The donkey neonate. In: Veterinary Care of Donkeys (Matthews, N.S., and Taylor, T.S., eds.), International Veterinary Information Service, Ithaca.

2. Carluccio, A., Panzani, S., Tosi, U., Riccaboni, P., Contri, A., and Veronesi, M.C. 2008. Morphological features of the placenta at term in the Martina Franca donkey. Therio- genology 69: 918-924. [Medline] [CrossRef]

3. Crisman, M.V., and Scarratt, W.K. 2008. Immunodeficiency disorders in horses. Vet. Clin. North Am. Equine Pract. 24: 299-310, vi. [Medline] [CrossRef]

4. Erhard, M.H., Luft, C., Remler, H.P., and Stangassinger, M. 2001. Assessment of colostral transfer and systemic availability of immunoglobulin $\mathrm{G}$ in new-born foals using a newly developed enzyme-linked immunosorbent assay (ELISA) system. J. Anim. Physiol. Anim. Nutr. (Berl.) 85: 164-173. [Medline] [CrossRef]

5. Jeffcott, L.B. 1974. Some practical aspects of the transfer of passive immunity to newborn foals. Equine Vet. J. 6: 109-115. [Medline] [CrossRef]

6. Jeffcott, L.B. 1974. Studies on passive immunity in the foal 1. Gamma-globulin and antibody variations associated with the maternal transfer of immunity and the onset of active immunity. J. Comp. Pathol. 84: 93-101. [Medline] [CrossRef]

7. LeBlanc, M.M., Tran, T., Baldwin, J.L., and Pritchard, E.L. 1992. Factors that influence passive transfer of immunoglobulins in foals. J. Am. Vet. Med. Assoc. 200: 179-183. [Medline]

8. McGuire, T.C., Crawford, T.B., Hallowell, A.L., and Macomber, L.E. 1977. Failure of colostral immunoglobulin transfer as an explanation for most infections and deaths of neonatal foals. J. Am. Vet. Med. Assoc. 170: 1302-1304. [Medline]

9. Sellon, D.C. 2001. Investigating outbreaks of respiratory disease in older foals. Proc. Am. Assoc. Equine Pract. 47: 451-455.

10. Sellon, D.C., and Johnson, J. 2006. Neonatal Immunology. pp. 31-50. In: Equine Neonatal Medicine: A Case-based Approach, 1st ed. (Paradis, M.R. ed.), Saunders Elsevier, Philadelphia.

11. Silva, C.A.M., Rubin, M.I.B., Waihrich, F.L., and Pelegrini, J.L.M. 1984. Diagnóstico da imunidade passiva adotiva adquirida através do colostro no potro recém-nascido. Pesqui. Vet. Bras. 4:(Suppl 1): 11-15.

12. Veronesi, M.C., Dall'Ara, P., Gloria, A., Servida, F., Sala, E., and Robbe, D. 2014. IgG, IgA, and lysozyme in Martina Franca donkey jennies and their foals. Theriogenology 81: 825-831. [Medline] [CrossRef] 